\title{
THE ROLE OF EMBROIDERY AND HOME WORK IN THE DEVELOPMENT OF ENTREPRENEURSHIP IN UZBEKISTAN
}

\author{
Nilufar Mustaqimovna Rakhmatova \\ Independent Researcher Navoi State Pedagogical Institute Navoi, Uzbekistan
}

\section{ABSTRACT}

This article discusses the creation of favorable economic and social conditions for the revival of forgotten traditional handicrafts in Uzbekistan in recent years and the future development of its surviving varieties. In the Soviet era, domestic labor was initially opposed for political and ideological reasons, but later, under the notion of "self-employment," domestic production was not strongly opposed, but not enough attention was paid to its development.

KEYWORDS: - Favorable economic, social conditions, traditions, handicrafts, Uzbekistan, development, surviving varieties, Soviet era, domestic labor, political reasons, ideological reasons, domestic production, employment, attention, traditional culture, material culture.

\section{INTRODUCTION}

Uzbekistan is one of the few countries in the world where traditional crafts play an important role in traditional and material culture. Effective efforts in this direction are fully reflected in the study of ancient and medieval art monuments, traditional crafts, folklore, cultural heritage, which are considered spiritual and cultural heritage. In recent years, Uzbekistan has created the necessary economic and social conditions for the revival of forgotten traditional crafts and the future development of its surviving types.

The Decree of the First President of the Republic of Uzbekistan IA Karimov № 1741 of March 31, 1997 "On measures to support the further development of folk arts and crafts through the state" was issued in this connection, in this regard, exemplary work has been done in the cities of the Fergana Valley, such as Andijan, Namangan, Fergana, Kokand, Margilan. In particular, craft associations were established in all of these cities, which were engaged in the development of handicrafts in cities and villages, the restoration and continuation of handicraft traditions.

\section{THE MAIN FINDINGS AND RESULTS}

Embroidery has a special place in the handicrafts of the Uzbek people. Embroidery, a traditional type of handicraft, has an ancient history and has developed in almost all regions of Uzbekistan, preserving its traditions. In urban and rural neighborhoods, the family was engaged in tanning, jewelry, carpet weaving, embroidery, weaving, and more. If in large cities the population was usually engaged in farming in the early spring and autumn, in the autumn-winter it was mostly engaged in handicrafts. In the Soviet 
CURRENT RESEARCH JOURNAL OF HISTORY 2(5): 93-97, May 2021

DOI: https://doi.org/10.37547/history-crjh-02-05-21

ISSN 2767-472X

(C)2021 Master Journals

\section{Crossref dof 81 Google}

Accepted 25th May, 2021 \& Published 31 th May, 2021

era, domestic labor was initially opposed for political and ideological reasons, but later, under the notion of "self-employment," domestic production was not strongly opposed, but not enough attention was paid to its development.

If we pay attention to the history of embroidery, in order to preserve the craft of embroidery, it was necessary to create embroidery in harmony with the ancient traditions, all kinds of methods of making embroidery products, embroideries. Although handicrafts made by artisans are laborintensive, they are low-cost and are designed to meet the needs of the local population. Cotton fabrics woven by artisans or manufactured in the factory were considered the main material for embroidery. The textile industry is unique in different regions of Uzbekistan, and includes several industries, such as spinning, weaving and dyeing. The main raw materials of spinners were cotton, wool and silk.

The development of embroidery species was largely dependent on the sedentary, semisedentary nature of the population, nature, the availability of raw materials. In the regions of Uzbekistan, embroidery has traditionally been developed at home, mainly by women and girls. For women to weave fabric at home, cotton seeds were separated using a special tool "khalaji". Cotton and wool yarns are spun using a wheel. A variety of fabrics are made from spun yarn in a weaving machine called a "shop". The masters used local plants such as rhubarb, spinach, mango, ginger, pomegranate and walnut skins to make the color [1.7].

Doppi, jiyak, small and large embroideries are sewn in the embroidery centers of the Fergana Valley. The textile industry is also well developed here, especially in such centers as Namangan and Margilan. Made of cotton fabrics, alacha, chit, semi-semi-fabric, beqasam, banoras, adras, velvet, silk, satin, khonatlas. Ипак тўқиш хунари билан асосан, шахар хамда шахар атрофидаги қишлоқ ахолиси шуғулланган [2.5]. Handoperated looms are usually installed in the home of the artisan. One room has two or more looms, in which silk, semi-silk fabrics, satin are woven.

In the second half of the XIX century in the Fergana valley developed the art of embroidery. Chitgar masters used Islamic patterns, such as various flowers, leaves, almonds, pomegranates, as well as the moon and talismans. At present, black and red handicrafts are preserved in the Fergana Valley. In the early twentieth century, the markets in the major cities of the Fergana Valley differed from other regional markets by their density, the variety and quantity of goods sold, their structure, and the diversity of the ethnic composition of the market population. In the trade turnover of the markets, embroidery was the fabric used in embroidery, and women were the mainstay [3.56].

The development of embroidery in the Kashkadarya region was also associated with the historically formed way of life of the local population. The most widespread areas of traditional embroidery have long been considered to be the central and especially the north-eastern districts of the Shakhrisabz-Kitab school [4.8]. Carpets were widely used by nomadic and pastoral Uzbek tribes, as well as Turkmens and Arabs, who lived in the western and south-western part of Kashkadarya region. The population living in the foothills of the Nurata Mountains (White and Black Ridge) is made of printed felt, from simple woven shawls to bald carpets, julkhirs, koli carpets. The rarest example of Nurata carpets is the "shield type", which attracts attention with its elegance and unique charm. In Surkhandarya region, traditional embroidery has a long history of development, where the leading center of embroidery is Boysun district.

Based on the above information, it should be noted that embroidery alone plays an important 
CURRENT RESEARCH JOURNAL OF HISTORY 2(5): 93-97, May 2021

DOI: https://doi.org/10.37547/history-crjh-02-05-21

ISSN 2767-472X

(C)2021 Master Journals

\section{Crossref do) 81 Google}

Accepted 25th May, 2021 \& Published 31 ${ }^{\text {th }}$ May, 2021

role in the development of domestic labor in the country, and thus in the employment of the population, especially women (home-based work). Although home-based work is not a new direction in the development of our country, over the years of independence, its activity has become a revived, cultured and legally strengthened field. At present, labor resources, family structure, means of production in Uzbekistan ensure the development of homebased work. Craftsmanship is convenient, especially for sewing, embroidery, furniture making, etc., which require needlework.

Therefore, in order to ensure employment and employment in Uzbekistan, special attention was paid to the field of embroidery. First of all, centers for various areas of traditional handicrafts were established and workshops were restored. In 2002, Boysun, one of the major centers of traditional folk culture, together with the National Commission and the UNESCO Office in Uzbekistan, was recognized by UNESCO as a masterpiece of the Oral Intangible Heritage of Humanity, along with 18 cities around the world. In 2006 , about 570,000 jobs were created in the country due to the structural changes and growth rates in the economy, the development of small business and entrepreneurship, the rapid development of the service sector, the creation of conditions for people to engage in various forms of home-based work. Especially in 2006, homebased work was actively developed on the basis of cooperation with large industrial enterprises, which created more than 60,000 jobs [5]. For example, in Kasbi district of Kashkadarya region, which has a population of more than 170,000 people, 5,462 new jobs were created in 2013 under the program of job creation and employment, and this year about 80 women engaged in handicrafts were provided with employment records. The first President created the conditions for home-based enterprises on the basis of the relevant decree [6]. In this regard, the Decree of the First President of the Republic of Uzbekistan "On measures to encourage the expansion of cooperation between large industrial enterprises and production and services based on the development of homebased work" of January 5, 2006 According to it, the development of the "Regulations on homebased work" by the Cabinet of Ministers of the Republic of Uzbekistan was an important step in the development of handicrafts, as well as the opening of home-based work [7]. In this regard, the first President of the Republic of Uzbekistan said: "In order to establish home-based work, which does not require large investments, we have given various machines and equipment to local people and families. As a result, 60,000 families received additional income. These people, so to speak, have changed their worldview. They now live in front of their families and children, contribute to the development of the country and the Motherland [8]," emphasized.

Based on international experience, in order to restore old technologies, natural dyes, use the classic patterns of the leading centers of Uzbek textiles in harmony with the market situation and marketing, The UNESCO Office in Uzbekistan has proposed to hold the Atlas Bayrami Festival of Traditional Textiles in 2015 in Margilan, Uzbekistan, where dynastic masters and leading designers have applied for a UNESCO Quality Certificate on a competitive basis. In this regard, the UNESCO Office in Uzbekistan has implemented a number of projects aimed not only at the development and restoration of traditional crafts, but also their scientific understanding and promotion. Published a number of scientific literature - books, albums, articles and practical manuals on the technology of dyeing yarns, fabrics in folk textiles, held events with the involvement of foreign experts [9.9]. Naturally, these cases can be considered not only as the development of embroidery, but 
CURRENT RESEARCH JOURNAL OF HISTORY 2(5): 93-97, May 2021

DOI: https://doi.org/10.37547/history-crjh-02-05-21

ISSN 2767-472X

(C)2021 Master Journals

\section{Crossref dof 81 Google}

Accepted 25th May, 2021 \& Published 31 th May, 2021

also as the first steps towards the restoration of old traditions, the employment of women in domestic labor and the development of homebased work.

In recent years, with increasing attention to the field, special attention was paid to the organization of home-based work in accordance with the requirements of the times. The Action Strategy for the five priority areas of development of the Republic of Uzbekistan for 2017-2021 and, of course, Resolution of the President of the Republic of Uzbekistan "On measures to create favorable conditions for further development of cash” May 24, 2017 № PP-2996, Resolution of the Cabinet of Ministers of the Republic of Uzbekistan dated November 20, 2019 № 919 "On measures to further improve the system of employment of women, including the development of entrepreneurship" also played an important role [10]. According to the resolution, the types of home-based work include the production of textiles and knitwear, haberdashery, confectionery and bakery products, furniture, repair and maintenance of electrical products, horticulture and landscaping [11]. The document states that one of the most pressing issues is to increase the income of the family budget by further developing home-based work and expanding the use of financial resources for the purchase of modern machinery, equipment, raw materials and supplies.

In 2017, at the initiative of the Women's Committee of Uzbekistan, for the first time the Republican Forum of Women Entrepreneurs was held under the motto "The role of women's entrepreneurship in the development of society". Its purpose was to determine the prospects for the development of women's entrepreneurship in the country by supporting women's entrepreneurship and providing them with employment. The forum also discussed the topic "Opportunities and challenges in the employment of women in rural areas: international experience, ways to apply it in Uzbekistan" [12.7]. Issues related to the development of direct home-based work were also discussed here. Meanwhile, public control groups have been set up in the country to study the problems in women's lives. In total, more than 5 million homes were visited and measures were taken to address the issues raised by families. In particular, 22,000 families were prevented from divorce, 36,000 people were employed, and 14.5 thousand people were provided with soft loans. In his Address to the Parliament, President Sh. Mirziyoyev: "The situation of women in the field is very difficult, no one knows the pain of an ordinary woman, if the chairperson of women takes responsibility without sitting in meetings" [13], "Apart from the important issue of creating permanent jobs for women, the development of family business, home-based work, handicrafts and horticulture is also lagging behind," he said [14.281].

\section{Conclusion}

In conclusion, at the same time, in addressing the challenges of ensuring sustainable employment and income growth of the population of Uzbekistan, priority was given to the development of various forms of home-based work, including the expansion of cooperation with large industrial enterprises. Therefore, the role of home-based work in raising living standards has become especially important [15.5-9]. In this regard, the establishment of the "Consortium to support home-based work", the reduction of taxes, home-based work has also developed in the regions. Currently, the share of the population engaged in various silk products, confectionery, textiles, leather goods and other industries, especially home-based work, has increased in the provinces.

\section{ReFERENCES}


1. Hakimov A., Nosirova Z. Kosonsoy traditional embroidery // Echoes from Maziy. 1. (41). 2009. - P. 7.

2. Alimova $\mathrm{N}$. The role of silk products in Turkestan exhibitions // Bulletin of the National University of Uzbekistan. 2016. №1-6, - P. 5.

3. Golovin I. Handicrafts of Turkestan.Tashkent:, 1909.-P.56.

4. Hakimov A., Nosirova Z. Kosonsoy traditional embroidery // Echoes from Maziy.1.(41). 2009. - P. 8.

5. Karimov I.A. Our main task is to move more consistently on the path of renewal and sustainable development, to create a prosperous life for our people. Report to the Cabinet of Ministers on the results of socio-economic development of the republic in 2006 and the most important priorities for deepening economic reforms in 2007. February 12, 2007 // People's speech. February 13, 2007.

6. Uzoqov Yu. Home-based work, house work // Voice of Uzbekistan. December 19, 2013.

7. The word of the people. January 6, 2006.

8. Karimov I.A. Our main task is to move more consistently on the path of renewal and sustainable development, to create a prosperous life for our people. Report to the Cabinet of Ministers on the results of socio-economic development of the republic in 2006 and the most important priorities for deepening economic reforms in 2007. February 12, 2007 // People's speech. February 13, 2007.

9. Hakimov A. Artistic handicrafts of Uzbekistan in the period of independence // Echo from Maziy.3(59). 2013. - P. 9.
10. Resolution of the Cabinet of Ministers of the Republic of Uzbekistan "On measures to create favorable conditions for further development of home-based work" Resolution "On measures to further improve the system of employment of women, the development of entrepreneurship among them" // lexUZ.

11. Resolution of the President of the Republic of Uzbekistan dated May 24, 2017 № PP2996 "On measures to create favorable conditions for further development of home-based work" // LexUZ

12. Hasanov.R. Theoretical interpretation of family, household and household // Economics and education. -№1. 2015. - P. 7.

13. The word of the people. January 5, 2020.

14. Shavkat Mirziyoev. We will resolutely continue our path of national development and take it to a new level. - Tashkent: Uzbekistan,2017. - P.281.

15. Hasanov R. Economic and social necessity of home-based work in Uzbekistan // Business expert 2018. №9 (129). P. 5-9. 